\title{
The head of a young bearded man from Medinet Madi
}

\section{Roberto Buongarzone ${ }^{1}$}

In Medinet Madi, during ISSEMM 2 sand removal works ${ }^{1}$ in 2009, the head of a bearded man was found in the so-called North Cult Place (Pls.1-2), a depression in the north part of the Roman Square north of the main tample (Temple A+B). The main architectural feature of this building, probably of Ptolemaic origin and successively covered by the pavement of the square, is a small mud brick chapel in its centre. We found there huge foundations and scattered architectural elements surrounding the chapel. The finds were numerous and important: beside the head discussed in this paper, many fragments of private statues were found together with hundreds of fragments of a great gypsum composition, with many figures of different sizes, one of them colossal, maybe a Sarapis ${ }^{2}$ (Pls.3-4). The place was certainly considered of utmost importance at the beginning of the Roman Empire. The Egyptian chapel at its centre, in axis with Temple A, could be older and made to contain the sacred cobra, the living hypostasis of the goddess Renenutet, as Edda Bresciani conjectures. The large hypaethral structure was probably accessible through a staircase now lost - on its south side, and was entirely surrounded by massive limestone walls.

The head (Pls. 5-8) is made in fine limestone; it has a hair of thick curls. The right front of the head is cut to the height of the eyebrows; on the attachment on the bulk of the head there are concretions that prevent the adherence of both parties. Around the contour of the eyes traces of red are visible, black on the preserved eyebrow. The whiskers are short, a short beard surrounds the cheeks, but the facial features, especially the nose, are disfigured by mutilation. The preserved part of the head, from the neck to the top of the head, measures $29 \mathrm{~cm}$. in height. The type of the head of Medinet Madi would seem at first glance the portrait of an emperor. Emperor statues were very common in Egypt at certain times. Inventories such as those in the temples of Oxyrhynchus and Kinopolis, at the time of Caracalla, prove that every temple and every village in Egypt had a portrait of the emperor, of his father and his mother. Besides, the ostraka prove that subscriptions for the erection of statues or busts of emperors could be made more than once in the same realm. ${ }^{3}$ The emperor statues until the time of Caracalla were made certainly of marble or limestone, while only Egyptian style statues could be in Egyptian stone (basalt, granite or porphyry). At least in the Byzantine period it is well known the custom to notify the advent of an emperor by sending his 
portraits to the most important cities in the empire. From these "originals", portraits were performed that ended up all over the country. ${ }^{4}$

After Hadrian, some features are generalized throughout the empire: plastic indication of the pupil and the iris, smoothing of the marble surface, use of the drill for hair and beard. In Egypt the use of the drill, however, is extremely limited, and is absent in the head of Medinet Madi. Regarding the eyes, there are some particularities. In Egypt, as in Athens and Rome, towards the end of the reign of Trajan the details of the eyes are not yet fully specified, with only the iris carved. ${ }^{5}$ This is because the sculptor tended to delineate only the field where the painter would have defined the work. It is only when the use of paint tends to disappear that the sculptor gradually outlines the details of the eye as well. In the head of Medinet Madi the carving of the iris is clear, but at the same time there are traces of color. However, in Egypt, the use of paint lasts much longer than elsewhere, and it is thus refuted the old assertion that the use the color in the portraits ceases starting from the Antonini. ${ }^{6}$ Still in the third century the details of the eye are not yet marked by chiseling and yet the drill is not employed to animate the colors of hair. Some heads in limestone or gypsum appear to have received a yellow artificial patina, intended to give the illusion of marble. ${ }^{7}$ The statues of Graeco-Roman style are, as well as from the capital, from Athribis, Terenouthis, Leontopolis in the Delta, Hermopolis in Upper Egypt. But not all the portraits found in the province have been manufactured there. The Alexandrian sculptors sent off sometimes their works up to Upper Egypt, as it is evidenced by a papyrus dated to $140 \mathrm{CE}^{8}$

It is also assumed that the imperial portraits were imported into Egypt, but rather it is true that the Egyptians drew on their imperial portraits, and, as we shall see, even of individuals on the basis of models sent from Rome to Alexandria. In fact, materials and style of the imperial effigies not differ from those of individuals. And therein lays the main problem of interpretation of the head of Medinet Madi. Is it really a head of an emperor or instead a head of an individual that imitates an imperial model?

\section{Models comparable with the head of Medinet Madi:}

One of the most similar portraits is certainly the bust in marble from Tell Abu Billo, Egyptian Museum in Cairo CG 44671, assigned by Graindor to Aelius Verus ${ }^{9}$ (Pl. 9) based on the extraordinary resemblance to the bronze bust of Aelius Verus of the British Museum: ${ }^{10}$ the details of the curls and the eyebrows are quite similar, as the beard, which forms a thin crown on his cheeks and chin. Before his death Hadrian raised statues to him who was to succeed him throughout the Empire. The portraits of Marcus Aurelius, which in some way resemble the head of Medinet Madi, ${ }^{11}$ display the use of the drill; the beard is absent in the early portraits, while it is more 
pronounced in the mature portraits, as the mustache, and covers the cheeks as well. The head of Septimius Severus in Egyptian Museum in Cairo ${ }^{12}$ (CG 2748) has in common with that of Medinet Madi the type of beard and the sculpture of the iris alone, but I am not sure that the Medinet Madi portrait had not the pupil, then eventually damaged; besides, the hair is shorter and just moved, eyebrows thinner and more stylized.

Recently, it has been by many scholars doubted the attribution of numerous portraits of the emperors. Günter Grimm has reconsidered the "imperial" attribution of many portraits by Graindor; he argues that almost always we deal with influence of imperial portraits on those of private individuals ${ }^{13}$. Hans Goette, about the portrait of Cairo attributed from Graindor to Aelius Verus and other similar cases, claims that the hair, even in the absence of the starred diadem, is typically Egyptian, and adds that the type of garment and the contexts of discovery make plausible the attribution of similar portraits to a circle of people linked to the cult of Serapis in Roman times. ${ }^{14}$ Many priests of Serapis would indeed have played civil duties within the Roman system and this would explain the use of the toga. And we cannot of course doubt that the Medinet Madi bearded man wear a toga. Kiss re-examines the issue of imperial portraits in Egypt: ${ }^{15}$ after a period of great abundance of imperial portraits under Augustus, then a good number (3 or 4) of Vespasian, we are seeing a decline. We do not know in fact any imperial portrait in Egypt of Titus, Domitian and Nerva, only one of Trajan. With Hadrian things change substantially. As it had happened with Vespasian in Alexandria, the journey of 130-131 increases the popularity of the effigies of the emperor in Egypt, dedicated to the renewal of the sensitivity of the Hellenistic period. Antoninus Pius did not show any particular interest in Egypt. The only portrait certainly attributable to him is CG 41650, ${ }^{16}$ while the bas-relief CG 27568 would not because of the diadem, characteristic of the priests. ${ }^{17}$ Therefore Kiss agrees with the interpretations of Parlasca and Grimm, ${ }^{18}$ that we are dealing with private individuals of the time of Antoninus Pius, who may be dated to $150 \mathrm{CE}$.

The bust CG 44671 attributed to Aelius Verus would be a private of $150 \mathrm{CE}$, as also Grimm states. The treatment of the eye, with an indication of the iris and pupil, remembers certainly the portrait of Medinet Madi, the pupil of which is lost, as the shaping of beard and eyebrows sculpted in short strokes. In both portraits the curls are very soft, barely carved. The straightforward and clear design is replaced here by an all plastic and pictorial approach, near what is called the Eastern Hellenistic style. The young "Marcus Aurelius" CG 39468 (Pl. 10), an attribution refused by Kiss, Adriani, Wegner, Parlasca, Bonacasa and many others ${ }^{19}$, might have in common with the Medinet Madi portrait the treatment of curls, which are however in strong chiaroscuro and display extensive use of the drill. 


\section{Chronological conclusions:}

From this review of the portraits of imperial type or imitation, it emerges that in a given period must have existed in Egypt one or more different ateliers, if not a school, that carved portraits or busts on the model of imperial portraits for the local people of high society. The temperament of these portraits depended on the different artists, but it remains as a common characteristic the research of the plastic, sometimes pictorial effect, rendered through a precise incision, a soft shaping and a baroque chiaroscuro. Such trends are occurring in all the art of the empire, but here they have a local character derived from the traditions of the eastern Hellenism. ${ }^{20}$ Regarding the dates of this group of imperial style portraits, in which we can include the head from Medinet Madi, the connection with the young Marcus Aurelius and his family made most of the scholars hypothesize the dates 140-150 CE. According to Kiss instead there would be no reason not to date the activity of this school in the late Antonine kingdom, towards the reign of Commodus, when the style of this Egyptian school neared its trends (but not the execution) to the Baroque in force throughout the Empire ${ }^{21}$.

The portrait of Medinet Madi seems to date back to the Hadrian or maximum Antoninus Pius age, on the basis of its similarity with the bust CG 44671 (attributed by old scholars to Aelius Verus). It would be surely attractive to connect this sculpture with the supposed visit of Hadrian at Medinet Madi, attested by the famous Demotic ostrakon 298, ${ }^{22}$ during which Hadrian would have stayed with five priests of the city. The emperor arrived in Tebtynis the $1^{\text {st }}$ of December $130 \mathrm{CE}$, during his return journey from Thebes to Alexandria. ${ }^{23}$ We do not know if really Hadrian visited Medinet Madi, or whether he had received the priests of the city in Tebtynis or elsewhere in Fayum; but the very fact that the ostrakon remembers the event about 60 years later at the time of Septimius Severus, is an indication of how much the visit of the emperor was regarded as epoch-making in the

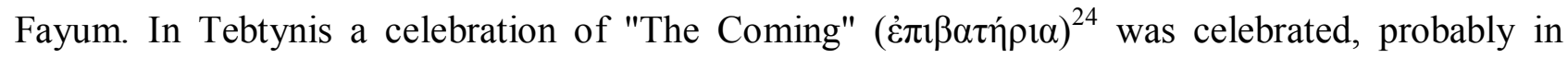
memory of the visit of Hadrian. According to Sijpesteijn Tebtynis is likely to have been only the place of entry into the Arsinoite, coming from Oxyrhynchus, and he argues that the emperor had also visited other places in the Fayum, including the Labyrinth, successively visited by his imitator Septimius Severus during his trip to Egypt. ${ }^{25}$ In this context it is not surprising that the majority of Roman statues in Medinet Madi may have been erected following the visit of the emperor, even after some years. 


\section{Notes:}

${ }^{1}$ In 2008 the second phase of the Italian-Egyptian cooperation program ISSEMM (Institutional Support to Supreme Council of Antiquities for Environmental Monitoring and Management) was started. The main archaeological result of the sand removal is the dromos South-North, $230 \mathrm{~m}$. long, starting from the original access with the sacrifice's altar; four unique statues of lions and one of a lioness were discovered along its sides, and as well as Greek dedication inscriptions dated to the year 116 BCE. The most recent phase of ISSEMM project, ISSEMM 3 (2013-2014), still directed by Edda Bresciani and managed by Antonio Giammarusti, Hisham el-Leithy and the writer is currently opening the site to Visitors enhancing its facilities, as the Visitor Centre, and restoring the statues and other fragile monuments. .

${ }^{2}$ Some fragments could be part of a Sarapis crown. A few fragments were gilded with gold.

3 P. Graindor, Bustes et statues-portraits d'Égypte romaine, Recueils de Travaux publiés par la Faculté des Lettres, Université Égyptienne, Le Caire 1937, 18.

${ }^{4} \mathrm{P}$. Graindor, Bustes et statues-portraits d'Égypte romaine, 19.

${ }^{5} \mathrm{P}$. Graindor, Bustes et statues-portraits d'Égypte romaine, 24.

${ }^{6}$ A. Hekler, Die Bildniskunst der Griechen und Römer, Stuttgart 1912, XLII.

${ }^{7} \mathrm{P}$. Graindor, Bustes et statues-portraits d'Égypte romaine, 27.

${ }^{8} \mathrm{P}$. Graindor, Bustes et statues-portraits d'Égypte romaine, 29.

${ }^{9}$ P. Graindor, Bustes et statues-portraits d'Égypte romaine, 52, P1. XI. H. Rupprecht Goette, Studien zu Römischen Togadarstellungen; Beiträge zur Erschließung hellenistischer und kaiserzeitlicher Skulptur und Architektur, Band 10, Mainz am Rhein 1990, Tafel 60, 3 L81 Kairo.

${ }^{10}$ H. Beauchamp Walters, Catalogue of the bronzes, Greek, Roman, and Etruscan in the Department of Greek and Roman Antiquities, British Museum, London 1899, 151; R. Delbrück, Bildnisse römischer Kaiser, Berlin 1914, pl. 24.

${ }^{11}$ H. Beauchamp Walters, Catalogue of the bronzes, pls. XV, XVIa, b, far less simlilar the portrait in pl. XVII.

${ }^{12}$ H. Beauchamp Walters, Catalogue of the bronzes, N. 19, P1. XVIII.

13 G. Grimm, Kunst der Ptolemäer- und Römerzeit im Ägytptischen Museum Kairo, aufnahmen von D. Johannes, Mainz am Rhein 1975, 9, Tavv. 52-54.

${ }^{14}$ H. Rupprecht Goette, Studien zu Römischen Togadarstellungen, 73-74.

${ }^{15}$ Z. Kiss, "Etudes sur le portrait impérial romain en Egypte", Travaux du Centre d'Archéologie Méditerranéenne de l'Académie Polonaise des Sciences, Tome 23, Varsovie 1984, 56-64.

${ }^{16}$ Z. Kiss, "Etudes sur le portrait impérial romain en Egypte", 61; figs. 130-131.

${ }^{17}$ Z. Kiss, "Etudes sur le portrait impérial romain en Egypte", fig. 132. It is instead attributable to Antoninun Pius according to Graindor, Edgar, Bonacasa.

${ }^{18}$ Z. Kiss, "Etudes sur le portrait impérial romain en Egypte", 62; K. Parlasca, Mumienporträts und ägyptische Grabkunst aus römischer Zeit; eine Ausstellung der Schirn-Kunsthalle Frankfurt, 30. Januar bis 11. April 1999, Frankfurt: Schirn-Kunsthalle, 1999, 86; G. Grimm, Kunst der Ptolemäer- und Römerzeit, 21, n 26, pls. 49, 52-53.

${ }^{19}$ Z. Kiss, "Etudes sur le portrait impérial romain en Egypte", 63, figs. 139-140

${ }^{20}$ N. Bonacasa, Due note sul ritratto romano imperiale dell'Egitto. Palermo 1971, 14.

${ }^{21}$ Z. Kiss, "Etudes sur le portrait impérial romain en Egypte", 64.

${ }^{22}$ A. Menchetti, "Quando Adriano venne in Egitto. Un nuovo testo demotico sul viaggio dell'imperatore", in Egitto $e$ Vicino Oriente XXVII (2004), 27-31. See also S. Pfeiffer, "Der römische Kaiser und das Land am Nil, Kaiserverherung und Kaiserkult in Alexandria und Ägypten von Augustus bis Caracalla (30 v. Chr. - 217 n. Chr.)”, HISTORIA, Zeitschrift für Alte Geschichte, Heft 212, Stuttgart 2010, 158.

${ }^{23}$ A. Menchetti, "Quando Adriano venne in Egitto. Un nuovo testo demotico sul viaggio dell'imperatore", 29; P.J. Sijpesteijn, “A new document concerning Hadrian's visit to Egypt”, Historia XVIII (1969), 109-118.

${ }^{24}$ P.J. Sijpesteijn, "A new document concerning Hadrian's visit to Egypt", 115; S. Pfeiffer, "Der römische Kaiser und das Land am Nil, Kaiserverherung und Kaiserkult in Alexandria und Ägypten von Augustus bis Caracalla (30 v. Chr. 217 n. Chr.)", 164 e n. 861.

${ }^{25}$ P.J. Sijpesteijn, “A new document concerning Hadrian’s visit to Egypt”, 115 e n. 20 a, 111. 


\section{Plates :}

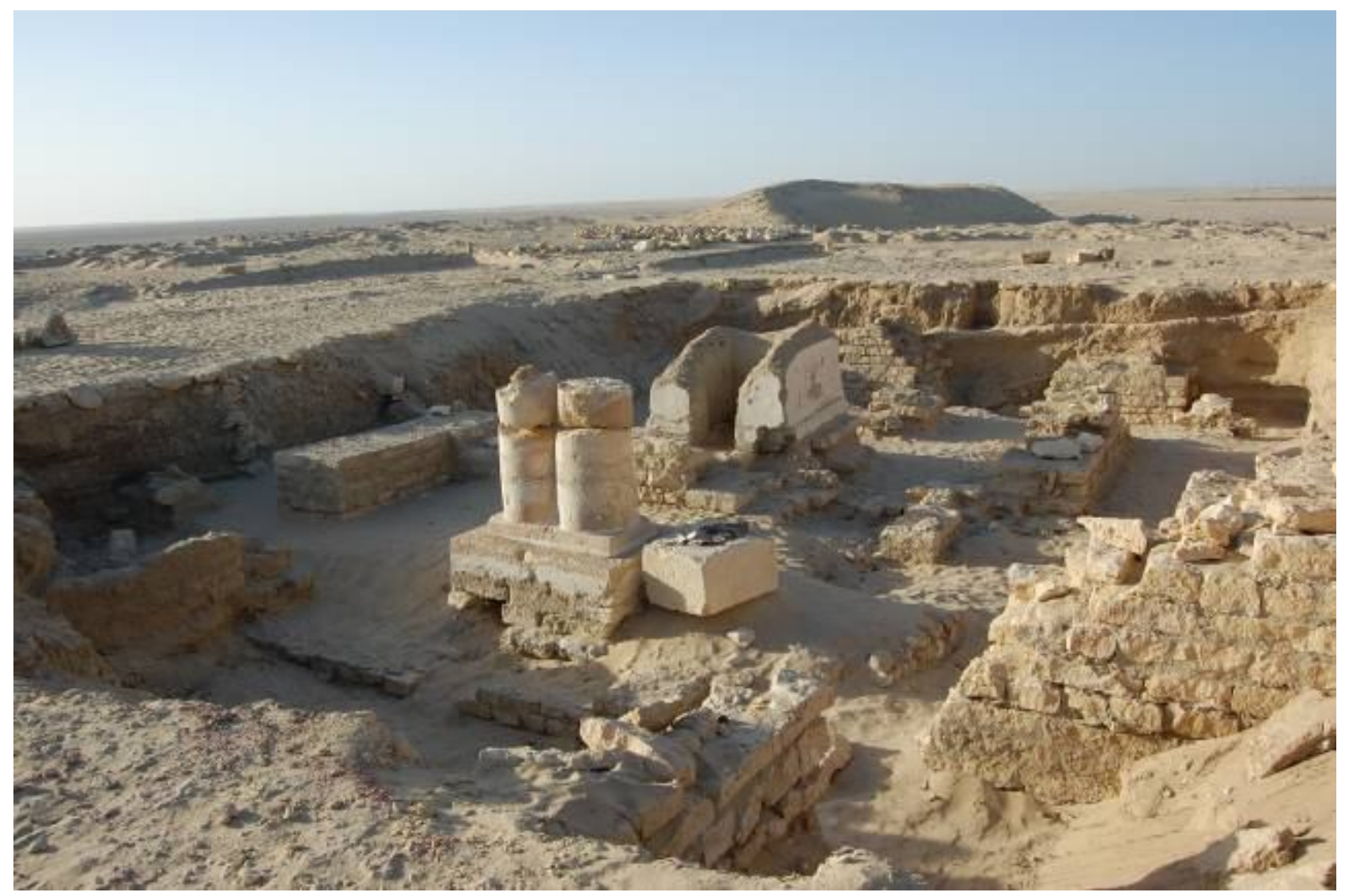

Pl. 1. The North Cult Place in the Roman Square, Medinet Madi.

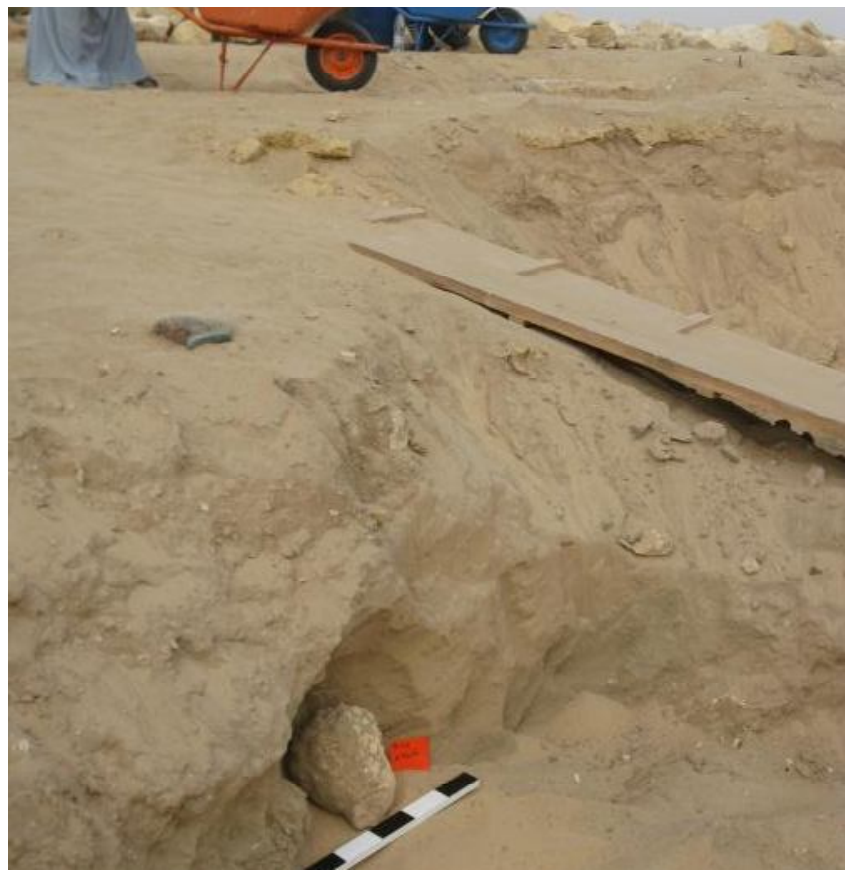

Pl. 2. The context of finding of the head. 

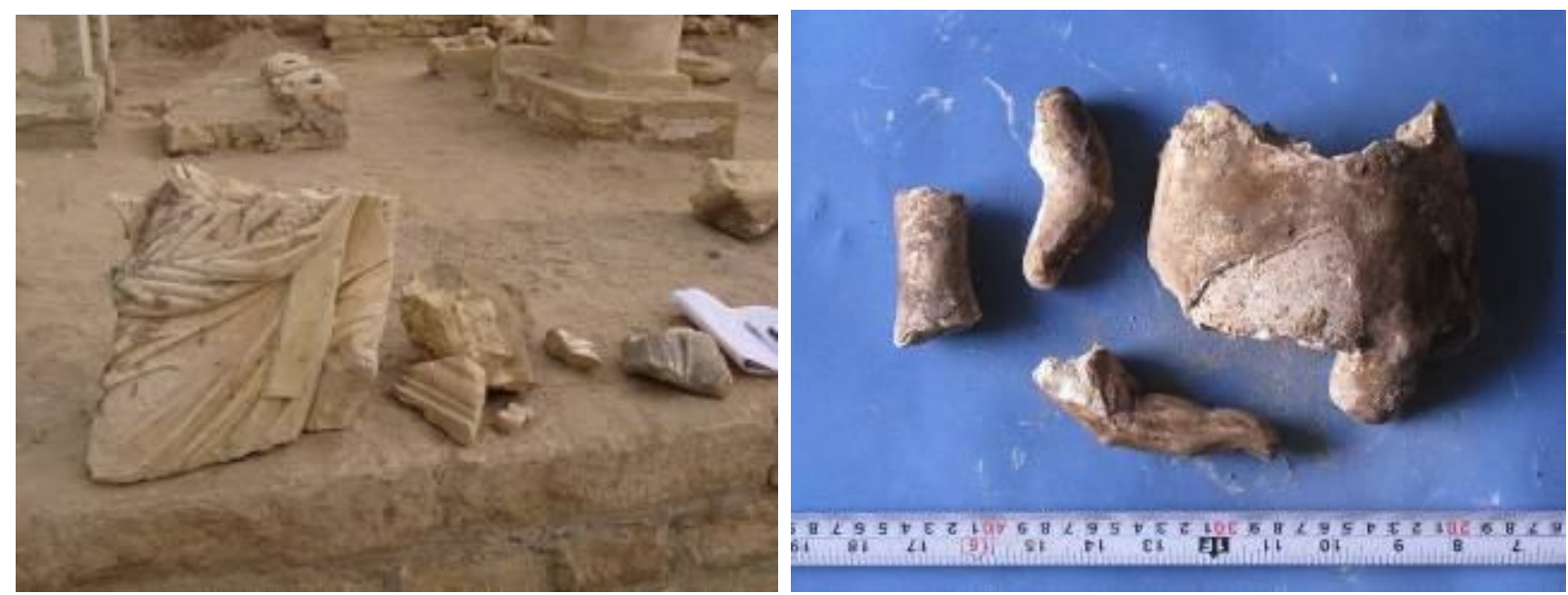

Pls. 3-4. Fragments of togati and of gypsum composition from the North Cult Place.
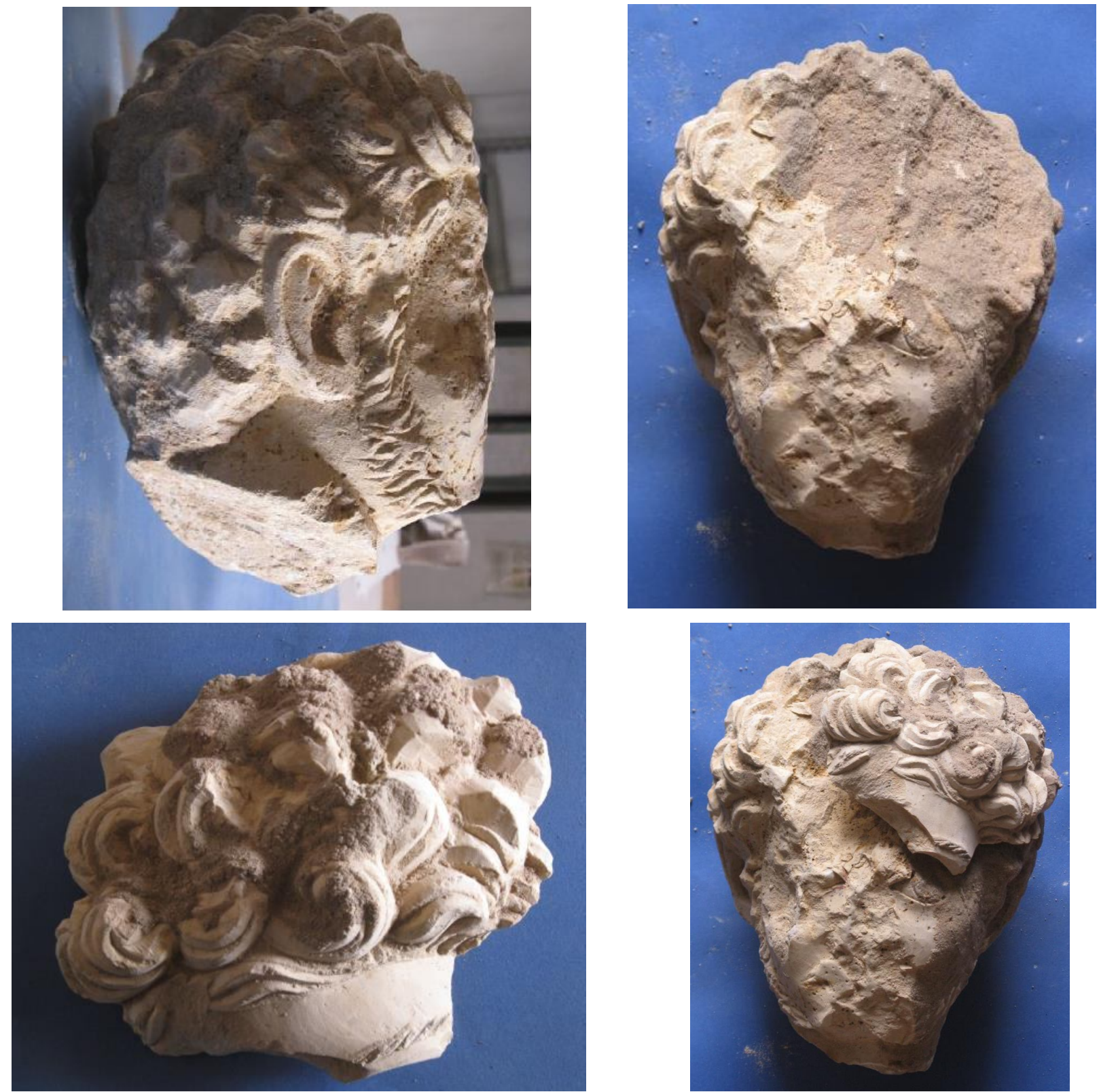

Pls. 5-8. The young bearded head of Medinet Madi 


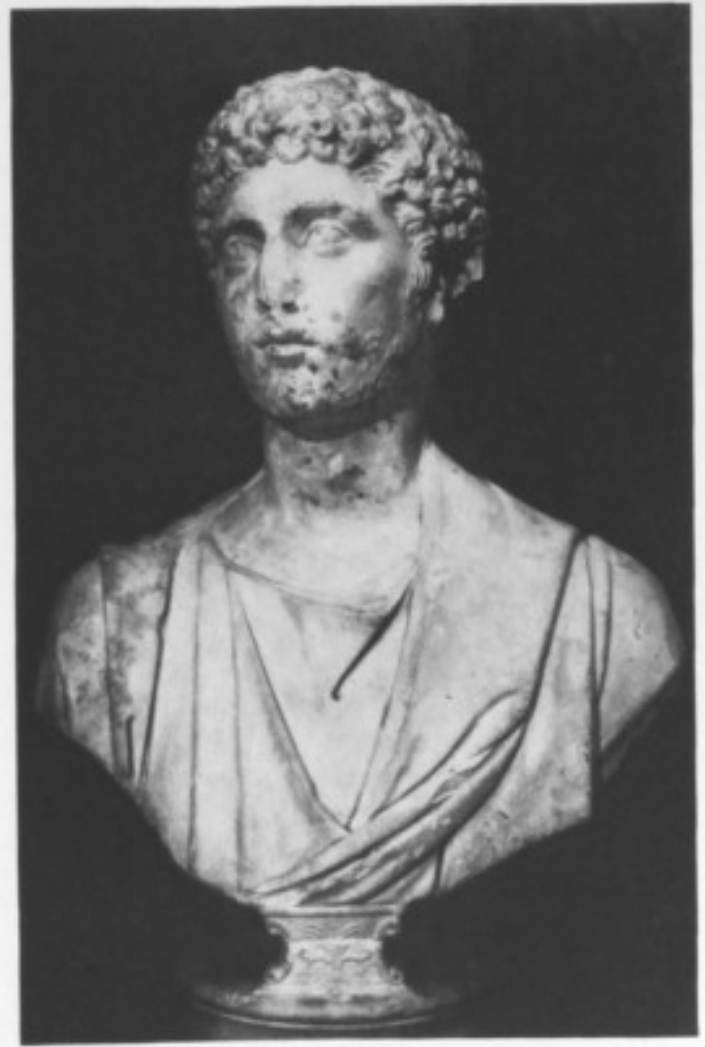

PI. XIa.

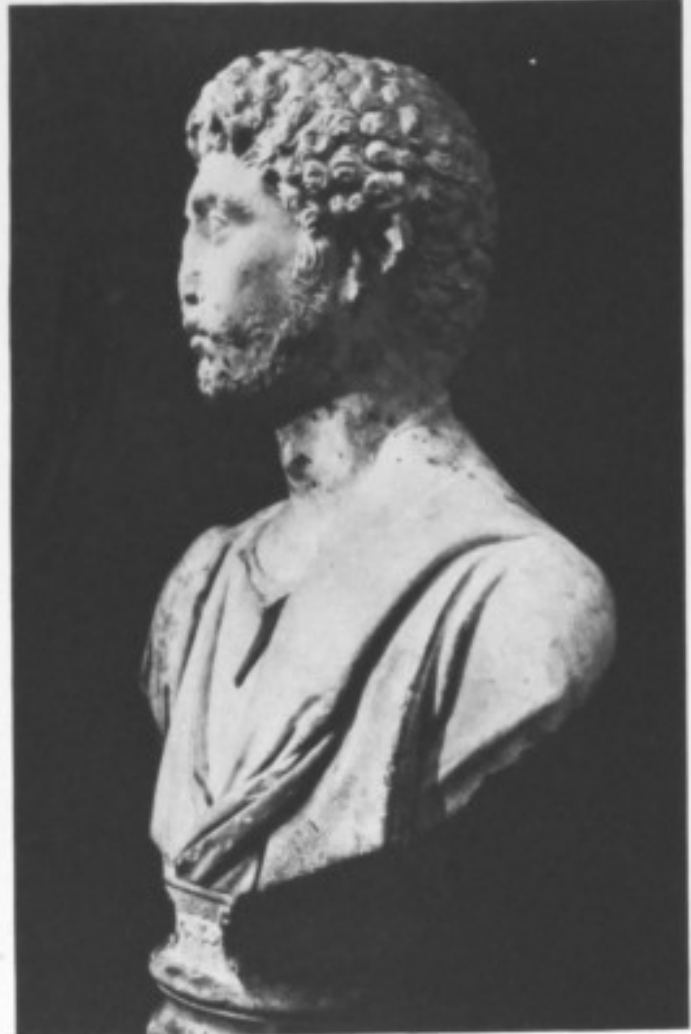

PI. XI b.

P1. 9. The "Aelius Verus" bust, CG 44671.

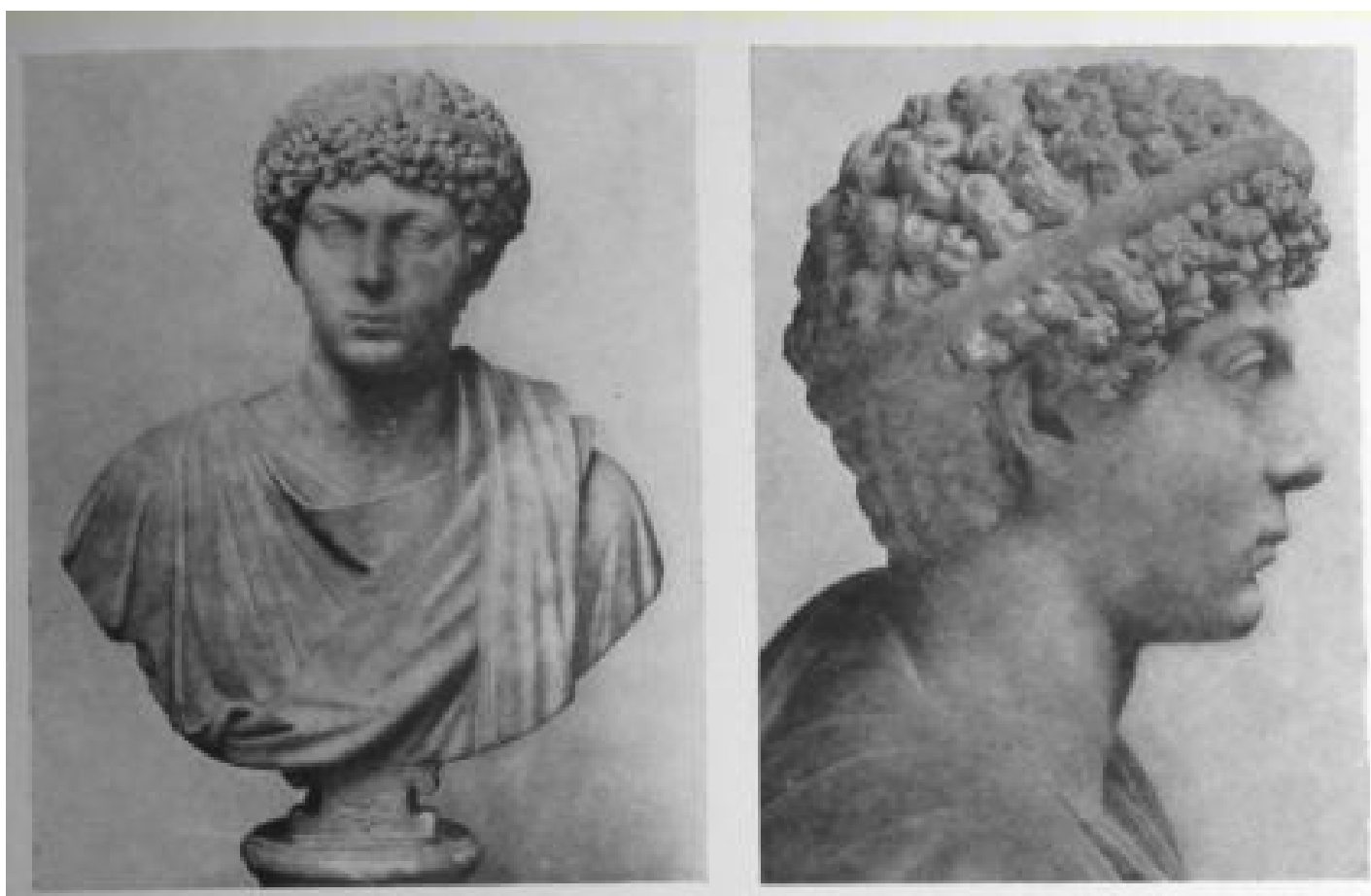

139-140. * Mare-Aurcle ", Le Cairc, Murke 39468 (phot, Johannes, DAIK-)

Pl. 10. The young Marcus Aurelius, CG 39468. 